\title{
Nitrous oxide emissions from soil during soybean [(Glycine max (L.) Merrill] crop phenological stages and stubbles decomposition period
}

\author{
Ignacio A. Ciampitti • Esteban A. Ciarlo • \\ Marta E. Conti
}

Received: 30 November 2006 /Revised: 7 August 2007 / Accepted: 9 August 2007 / Published online: 6 October 2007

(C) Springer-Verlag 2007

\begin{abstract}
The purpose of this study was to evaluate, during the phenological stages of inoculated soybean crop [Glycine $\max (\mathrm{L}$.$) Merrill], the effect of different \mathrm{N}$ fertilization levels and inoculation with Bradyrhizobium japonicum on $\mathrm{N}_{2} \mathrm{O}$ emissions from the soil. Gas emissions were evaluated at field conditions by the static-chamber method. Nitrogen fertilization increased $\mathrm{N}_{2} \mathrm{O}$ emissions significantly $(P<$ 0.05 ). The variable that best explained cumulative $\mathrm{N}_{2} \mathrm{O}$ emissions during the whole soybean growing season was the soil nitrate level $\left(r^{2}=0.1899 ; P=0.0231\right)$. Soil moisture presented a greater control on $\mathrm{N}_{2} \mathrm{O}$ emissions between the grain-filling period and the crop commercial maturity $\left(r^{2}=\right.$ $0.5361 ; P<0.0001)$, which coincided with a positive balance of the available soil $\mathrm{N}$, as a consequence of the decrease in crop requirements and root and nodular decomposition. Only soil soluble carbon $\left(r^{2}=0.29 ; P=\right.$ $0.019)$ and moisture $\left(r^{2}=0.24 ; P=0.039\right)$ were correlated with $\mathrm{N}_{2} \mathrm{O}$ emissions during the residue decomposition period. The relationship between soil variables and $\mathrm{N}_{2} \mathrm{O}$ emissions depended on crop phenological or stubbles decomposition stages.
\end{abstract}

Keywords Denitrification - Nitrification .

Greenhouse effect $\cdot$ Nitrogen

\section{Introduction}

Nitrous oxide, $\mathrm{N}_{2} \mathrm{O}$, is an important atmosphere component, which absorbs infrared radiation thus contributing to

I. A. Ciampitti $(\bowtie) \cdot$ E. A. Ciarlo $\cdot$ M. E. Conti

Edaphology Chair, Buenos Aires University,

Av. San Martín 4453,

CP 1417 Buenos Aires, Argentina

e-mail: ciampitt@agro.uba.ar the greenhouse effect (Mosier et al. 1996), and is produced in soil mostly by nitrification and denitrification processes (Rochette et al. 2004). Agricultural systems are considered responsible for about 20 to $70 \%$ of the anthropogenic $\mathrm{N}_{2} \mathrm{O}$ that is released to the atmosphere (Marinho et al. 2004). It has been considered that around $10 \mathrm{Tg}$ of $\mathrm{N}-\mathrm{N}_{2} \mathrm{O}$ is directly injected to the atmosphere every year only as result of fertilizers use (Watson 1992).

Several parameters were identified to affect the rate of $\mathrm{N}_{2} \mathrm{O}$ production from agricultural systems, including $\mathrm{N}$ availability (Bouwman 1996; Brown et al. 2000; Maggiotto et al. 2000), temperature (Goodroad and Keeney 1984; Castaldi 2000), pH (Daum and Schenk 1998; Mogge et al. 1999), and soil moisture (Dobbie et al. 1999; Zheng et al. 2000). Mosier et al. (1996), which suggested that the conditions that increase $\mathrm{N}_{2} \mathrm{O}$ production are high mineral $\mathrm{N}$ and organic $\mathrm{C}$ availability and middle-high moisture level that limits oxygen $\left(\mathrm{O}_{2}\right)$ diffusion.

The introduction of leguminous plants in agricultural systems can increase food production, but the biological nitrogen fixation can contribute to the $\mathrm{N}_{2} \mathrm{O}$ emission in several ways (Yang and Cai 2005). Duxbury et al. (1982) suggested that leguminous plants may increase $\mathrm{N}_{2} \mathrm{O}$ emissions two to three times with respect to nonfertilized soils. The Bradyrhizobium japonicum bacteria that are associated to the leguminous crop in radical nodules can fix atmospheric $\mathrm{N}$ but also carry out denitrification with production of $\mathrm{N}_{2} \mathrm{O}$ (Mosier et al. 1996). The soybean [(Glycine $\max$ L.) Merrill] is one of the most important crop components in Argentina, occupying an area of about 15.2 million hectares with a grain production of 36.5 million tons (INDEC 2005). The soybean crop can affect $\mathrm{N}_{2} \mathrm{O}$ emissions in different ways: by taking up water and $\mathrm{NO}_{3}^{-}$ from soil, thus reducing $\mathrm{N}_{2} \mathrm{O}$ emissions, or by releasing soluble $\mathrm{C}$ and $\mathrm{N}$ with increase in microbial activity and 
consequent reduction in the rhizosphere $\mathrm{O}_{2}$ concentration, thus increasing $\mathrm{N}_{2} \mathrm{O}$ emissions.

The stubbles $\mathrm{C} / \mathrm{N}$ ratio is inversely related to the initial decomposition rate of stubbles: therefore, crops with a low $\mathrm{C} / \mathrm{N}$ ratio like soybean display high decomposition rates, with possible release of $\mathrm{NO}_{3}^{-}$, and this may increases in $\mathrm{N}_{2} \mathrm{O}$ emissions (Aulakh et al. 1991a). However, most of the published studies regarding $\mathrm{N}_{2} \mathrm{O}$ emissions from soil under leguminous crops depended on the growing season (Aulakh et al. 1991a; Marinho et al. 2004; Yang and Cai 2005). At the present, there is little knowledge about $\mathrm{N}_{2} \mathrm{O}$ emissions from the soil under soybean growing season and during stubbles decomposition. It has been hypothesized that $\mathrm{N}_{2} \mathrm{O}$ emissions can increase because of inoculation with nitrogen-fixing bacteria and $\mathrm{N}$ fertilizers application, common practices for the soybean crop grown in the Argentinian Pampean Region (Ciampitti et al. 2005). The aim of this work was to study the effects of the inoculation of soybean with $B$. japonicum on $\mathrm{N}_{2} \mathrm{O}$ evolution during all phenological stages and during the stubbles decomposition period in the presence of $\mathrm{N}$ fertilizers.

\section{Materials and methods}

\section{Soil characteristics}

The experiment was carried out in the experimental field of the Agronomy College of the Buenos Aires University, located in Buenos Aires city, Argentina. The soil is a silty clay loam (34\% clay, $58 \%$ silt, and $8 \%$ sand) and was classified as a typic Argiudoll. At the beginning of the experiment, the soil presented the following chemical properties: $\mathrm{N}-\mathrm{NO}_{3}^{-} 4.08 \mathrm{mg} \mathrm{kg}{ }^{-1}$, content of organic $\mathrm{C}$ (Cox) $2.15 \%$, total $\mathrm{N}(\mathrm{Nt}) 0.20 \%$; $\mathrm{pH}$ in a 1:2.5 soil/distilled water suspension 6.8 , and extractable P $89 \mathrm{mg} \mathrm{kg}^{-1}$ (Bray and Kurtz 1945).

Field experiment, sampling, and analyses

The experimental field was divided in plots of $2 \times 2 \mathrm{~m}$, and the experimental design was a completely randomized design, with a factorial adjustment of three by three, with inoculation and fertilization as factors. Each treatment was replicated four times. Inoculation treatments were (1) plots sown with soybean inoculated with B. japonicum $\left(\mathrm{P}_{\mathrm{i}}\right),(2)$ plots sown with soybean without inoculation $\left(\mathrm{P}_{\mathrm{ni}}\right)$, and (3) without crop $\left(\mathrm{P}_{0}\right)$. The fertilization treatments were: without fertilization $\left(\mathrm{N}_{0}\right)$, and fertilization with $15\left(\mathrm{~N}_{1}\right)$ and $30\left(\mathrm{~N}_{2}\right)$ $\mathrm{kg} \mathrm{N} \mathrm{ha}{ }^{-1}$; the $\mathrm{N}$ fertilizer was urea, the most used $\mathrm{N}$ fertilizer in Argentina. Nitrogen fertilizers were only applied at the beginning of the experiment. Soybean seeds were inoculated with a liquid solution containing $10^{8}$ number of microorganism per $\mathrm{ml}$ of inoculant. On December 28, 2004, a transgenic soybean with RR gene (gliphosate resistant), cultivar "Don Mario" 4800, maturity group IV, having an indeterminate growth habit, was sown on plots. On May 3, 2005, 126 days after sowing, the soybean crop was manually harvested. Weeds were controlled with gliphosate herbicide applications. The length of the experiment included the soybean growth and harvest and the stubbles decomposition period, which lasted 80 days after harvest.

$\mathrm{N}_{2} \mathrm{O}$ measurements were done by the closed staticchamber method with PVC cylinders, $15 \mathrm{~cm}$ in length and $11 \mathrm{~cm}$ as internal diameter, according to Khera et al. (1999). The superior part of the cylinder was hermetically closed with a rubber septum cover through which the gaseous samples of the internal atmosphere were taken with a syringe. The cylinders were buried $8 \mathrm{~cm}$ into the soil and sealed carefully to prevent gaseous losses. Each measurement involved gas accumulation for $24 \mathrm{~h}$ into cylinders, to account for variations in daily temperature (Aulakh et al. 1991b) because it has been registered that the maximum can be five times higher than the minimum day flux (Williams et al. 1999). Three gaseous samples taken from the atmosphere were used as blanks. Once the samples were taken, they were immediately brought to the laboratory and analyzed by gas chromatography. The gas samples were taken every 2 weeks along the experiment and the sampling times corresponded to the following crop phenologic stages: sowing (S), one knot (V1), three developed knots (V3), flowering (R1), beginning of pods formation-fructification (R3), grain filling (R5.5), maximum grain size (R6.5), physiological maturity (R8), 17 days after harvest, the commercial maturity (MC), 59 days after harvest, the residues presence $(\mathrm{R})$, and 80 days after harvest, the residues decomposition (RD). In case of rainfall, sampling frequency was altered so as to include these events and to obtain reliable measurements (Sexstone et al. 1985). We used a gas chromatograph 6890 Agilent with ECD detector and a hair column Carboplot, using helium as carrier gas; the work temperatures were $100^{\circ} \mathrm{C}$ for the oven and injector and $250^{\circ} \mathrm{C}$ for the detector.

On the same days of gas sampling, soil samples $(0-20 \mathrm{~cm})$ were taken from plots. Moist soils were used for measuring soil moisture and $\mathrm{NO}_{3}^{-}$content and air-dried (at $40^{\circ} \mathrm{C}$ followed by sieving at $2 \mathrm{~mm}$ ) soils for measuring soil $\mathrm{pH}$, soil organic $\mathrm{C}$, and water soluble carbon.

Soil $\mathrm{pH}$ was measured in a 1:2.5 soil/distilled water suspension using a precalibrated glass electrode (Thomas 1996). Soil organic $C$ was evaluated by the Walkley-Black wet oxidation method (Nelson and Sommers 1982). Watersoluble C (Mazzarino et al. 1993) was extracted by stirring 
soil samples with distilled water (solid phase/solution 1:50) for $24 \mathrm{~h}$ at room temperature. The suspension was centrifuged at $19,500 \times \mathrm{g}$ for $10 \mathrm{~min}$, and the supernatant was filtered through a $0.4-\mu \mathrm{m}$ glass fiber container under vacuum filtering. Water-soluble $\mathrm{C}$ was determined by the dichromate oxidation method as reported for the determination of the organic $\mathrm{C}$ content. Soil moisture was calculated as the difference between fresh and dry weight (after drying at $105^{\circ} \mathrm{C}$ till constant weight). The $\mathrm{N}-\mathrm{NO}_{3}^{-}$ content of the moist superficial soil layer $(0-20 \mathrm{~cm})$ was determined by shaking $20 \mathrm{~g}$ of soil with $100 \mathrm{ml} 0.25 \%$ $\mathrm{CuSO}_{4}+0.01 \mathrm{M} \mathrm{BO}_{3} \mathrm{H}_{3}$ solution: The suspension was filtered and $\mathrm{NO}_{3}^{-}$determined by the hydrazine-reduction method (Carole and Scarigelli 1971).

\section{Statistical analysis and calculations}

We analyzed the fulfillment of the assumptions of variance homogeneity and normal distribution of the $\mathrm{N}_{2} \mathrm{O}$ emissions, by log-transforming emissions when necessary. Cumulative $\mathrm{N}_{2} \mathrm{O}$ emissions data were analyzed by standard two-way variance, with general linear procedures of the SAS Statistical Package (SAS Institute 1999) and with later separation of means by tests of multiple comparisons according to Duncan. Regression analyses between cumulative $\mathrm{N}_{2} \mathrm{O}$ emissions and the measured soil properties were done by the SAS PROC REG procedure by considering either the whole experiment or each period.

\section{Results and discussion}

Evolution of nitrous oxide emissions

Nitrous oxide emissions were low and stable during 100 days after sowing and increased after the grain-filling step. The greatest values occurred between grain filling and commercial maturity, in all treatments, even in those without plants $\left(\mathrm{P}_{0}\right)$, and as an average, $1,348 \mu \mathrm{g} \mathrm{N}-\mathrm{N}_{2} \mathrm{O} \mathrm{m} \mathrm{m}^{-2} \mathrm{~h}^{-1}$ represented about $68 \%$ of total $\mathrm{N}_{2} \mathrm{O}$ emissions (Fig. 1). The greatest emissions $\left(5,516 \mu \mathrm{g} \mathrm{N}-\mathrm{N}_{2} \mathrm{O} \mathrm{m}{ }^{-2} \mathrm{~h}^{-1}\right)$ were observed at commercial maturity, i.e., 142 days after crop sowing, in plots fertilized with the highest $\mathrm{N}$ rate and inoculated with $\mathrm{N}$ fixing bacteria $\left(\mathrm{N}_{2} \mathrm{P}_{\mathrm{i}}\right.$; Fig. 1c). Yang and Cai (2005) also found out that about $94 \%$ of the total $\mathrm{N}_{2} \mathrm{O}$ emissions were concentrated in the last stages of the soybean crop cycle. Therefore, it is possible to consider this period as the most critical one for $\mathrm{N}_{2} \mathrm{O}$ emissions, during the soybean crop cycle (Ciampitti et al. 2005). During this period of high $\mathrm{N}_{2} \mathrm{O}$ losses, which is about 20 days before and 20 days after the harvest, the trend in $\mathrm{N}_{2} \mathrm{O}$ emissions was similar to that of $\mathrm{N}-\mathrm{NO}_{3}^{-}$levels and soil moisture contents (Fig. 5).

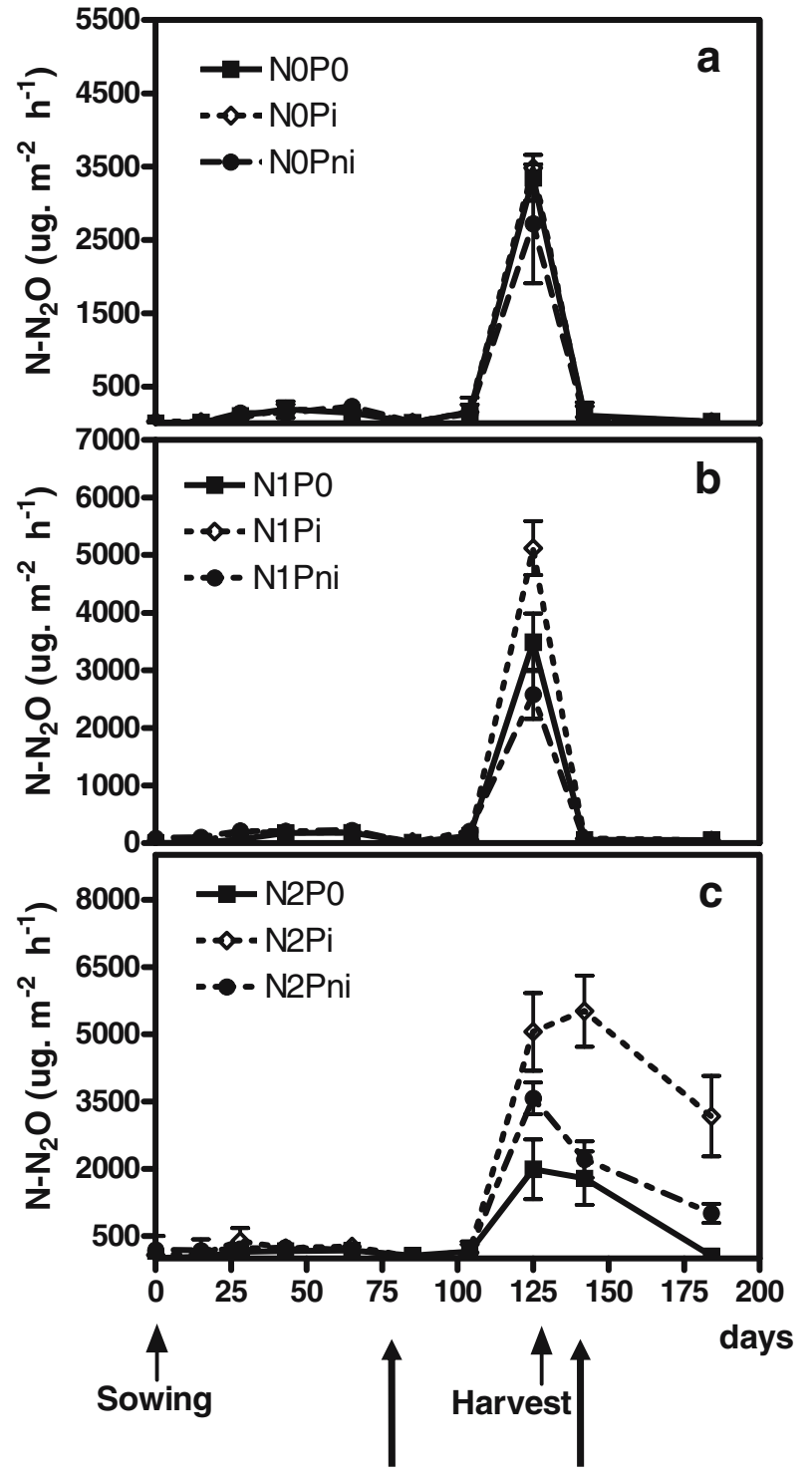

\begin{tabular}{|c|c|}
\hline R 5.5 Grain & MC- Stubbles \\
Filling & Presence \\
Day 84 & Day 142 \\
\hline
\end{tabular}

Fig. 1 Nitrous oxide emissions from plots without soybean plants $(P 0)$, with inoculated soybean $(P i)$, and with not inoculated plants $(P n i)$, under the following treatments: not fertilized $-N O(a)$, fertilized with $15 \mathrm{~kg} \mathrm{~N} \mathrm{ha}^{-1}-\mathrm{N1}$ (b), and fertilized with $30 \mathrm{~kg} \mathrm{~N}^{-1}-N 2$ (c). Points are average of three replications for each treatment. Error bars represented standard deviation

Effects of fertilization and inoculation on nitrous oxide emissions

Significant effects of the interaction between $\mathrm{N}$ fertilization and inoculation $(P=0.03)$ were detected on cumulative $\mathrm{N}_{2} \mathrm{O}$ emissions during the crop cycle. When the plots were fertilized with liquid urea, cumulative $\mathrm{N}_{2} \mathrm{O}$ emissions 


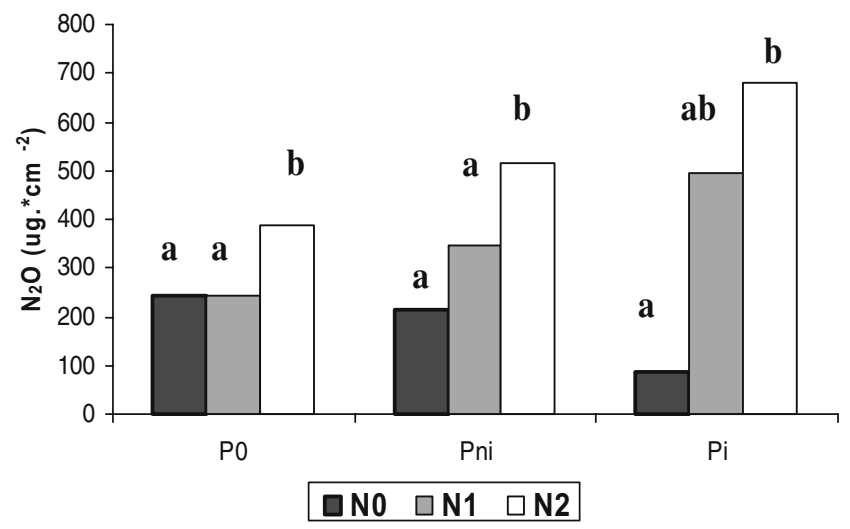

Fig. 2 Effect of the $\mathrm{N}$ fertilization (without fertilization- $N 0,15 \mathrm{~kg}$ $\mathrm{ha}^{-1}-N 1$, and $30 \mathrm{~kg} \mathrm{ha}^{-1}-N 2$ ) on cumulative $\mathrm{N}_{2} \mathrm{O}$ emissions, from plots without plants $(P O)$, with not inoculated soybean plants $(P n i)$, and plants inoculated with Bradyrhizobium japonicum (Pi). The separation of treatments was made by tests of multiple comparisons according to DUNCAN. Column with different letters are significantly different

increased with soybean plants, especially if seeds were inoculated with microorganisms $\left(\mathrm{P}_{\mathrm{i}}>\mathrm{P}_{n i}>\mathrm{P}_{0}\right)$, whereas in unfertilized plots, the crop presence decreased $\mathrm{N}_{2} \mathrm{O}$ emissions $\left(\mathrm{P}_{0}>\mathrm{P}_{\mathrm{ni}}>\mathrm{P}_{\mathrm{i}}\right.$; Fig. 2). Nevertheless, the inoculation factor did not significantly affect $\mathrm{N}_{2} \mathrm{O}$ emissions $(P>0.05)$ at any fertilization level.

In the treatments with inoculated plants, nodulation was observed in the secondary soybean roots. The average number of nodules at flowering stage was 15 in the inoculated plants $\left(\mathrm{P}_{\mathrm{i}}\right)$ and 6 in the noninoculated plots $\left(\mathrm{P}_{\mathrm{ni}}\right)$, independently on the fertilization levels. Some authors suggest that biological $\mathrm{N}$ fixation is an important $\mathrm{N}_{2} \mathrm{O}$ source (Mosier et al. 1996; Mosier 1998). Breitenbeck and Bremner (1989) suggested that although symbiotic fixing bacteria are able to denitrify $\mathrm{NO}_{3}^{-}$under anaerobic conditions, the population of these microorganisms is very small to have any important influence on denitrification rate in the soil.

Nitrogen fertilization significantly increased cumulative $\mathrm{N}_{2} \mathrm{O}$ emissions (Fig. 2), thus confirming what already reported (Kaiser et al. 1998; MacKenzie et al. 1998; Weitz et al. 2001; Ghosh et al. 2002). Fertilization treatments generated different $\mathrm{N}_{2} \mathrm{O}$ emissions, which were greatest at inoculated soybean plants; fertilization at $30 \mathrm{~kg} \mathrm{~N} \mathrm{ha}^{-1}$ (highest rate) increased $\mathrm{N}_{2} \mathrm{O}$ emissions by 1.6, 2.4 and 7.8 times in treatments without crop and not inoculated and inoculated plants, respectively. The percentage of $\mathrm{N}$ fertilizer lost as $\mathrm{N}-\mathrm{N}_{2} \mathrm{O}$ during all experiment (about 7 months) was 0.55 and $1.97 \%$, at fertilization rates of 15 and $30 \mathrm{~kg} \mathrm{~N} \mathrm{ha}{ }^{-1}$, respectively. These values are close to those reported by Bouwman (1996) and adopted per year by the Interguvernamental Panel of Climate Change (Houghton et al. 2001), although the period of our study was shorter than 1 year. Henault et al. (1998) found the same emission factors at any fertilizer rate.

Plant tissues with a low $\mathrm{C} / \mathrm{N}$ ratio (mean $\mathrm{C} / \mathrm{N}=44$, data not shown) such as soybean may stimulate microbial decomposition and release of easily available $\mathrm{C}$ and $\mathrm{N}$, favoring $\mathrm{N}_{2} \mathrm{O}$ emissions (Aulakh et al. 1991a). Highest emissions with a high level of $\mathrm{N}$ fertilization and with inoculated plants has been explained by Luciñski et al. (2002), as a result of the occurrence of "denitrification as a complementary process to nitrogenase"; indeed, high $\mathrm{NO}_{3}^{-}$ disemilatory reductase (NR) activity is characteristic of many symbiotic associations between legumes and rhizobia bacteria. In most species, this enzyme only occurs in nodule cytosol, but in soybean, dissimilatory NR activity has been also detected in bacteroids, where it accounts for $90 \%$ of total nodule NR activity (Hunter 1983). The synthesis of this enzyme is induced by $\mathrm{NO}_{3}^{-}$inside of bacteroids, and it does not depend on the type of Rhizobium strain investigated (Arrese-Igor et al. 1990). Denitrification may be involved in detoxification when high-cytosol NR activity can accumulate nitrite (Heckman and Drevon 1987). It would be important to measure the contribution of inoculated fixing bacteria to $\mathrm{N}_{2} \mathrm{O}$ emissions because if inoculated bacteria succeed in infecting the plant roots, the respective bacteriods may potentially be responsible of high $\mathrm{N}_{2} \mathrm{O}$ losses as they are carbohydrate rich.

Soil controls of $\mathrm{N}_{2} \mathrm{O}$ emissions during soybean crop-growing season

Fertilization effect may also be observed by the significant correlation between $\mathrm{N}_{2} \mathrm{O}$ emissions and $\mathrm{NO}_{3}^{-}$levels $\left(r^{2}=\right.$ $0.19 ; P=0.02$ ) during the growing season (Fig. 3a), as urea is rapidly hydrolyzed and converted to $\mathrm{NO}_{3}^{-}$in well-drained
Fig. 3 Relationship between $\log$ transformed $\mathrm{N}-\mathrm{N}_{2} \mathrm{O}$ emissions and $\mathrm{N}-\mathrm{NO}_{3}^{-}$in all treatments (a), only for inoculated plants during the soybean crop cycle (b). Dotted lines represent $95 \%$ confidence intervals
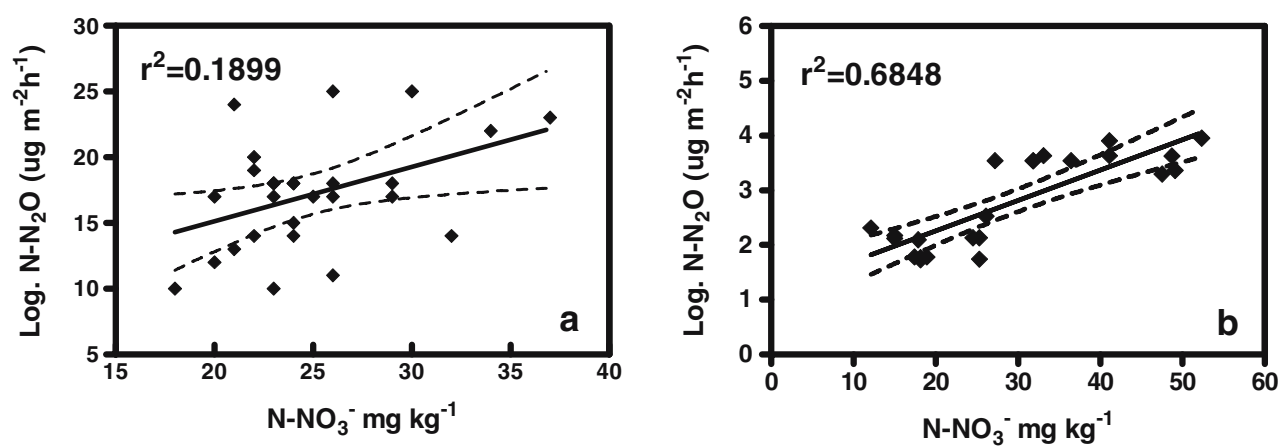


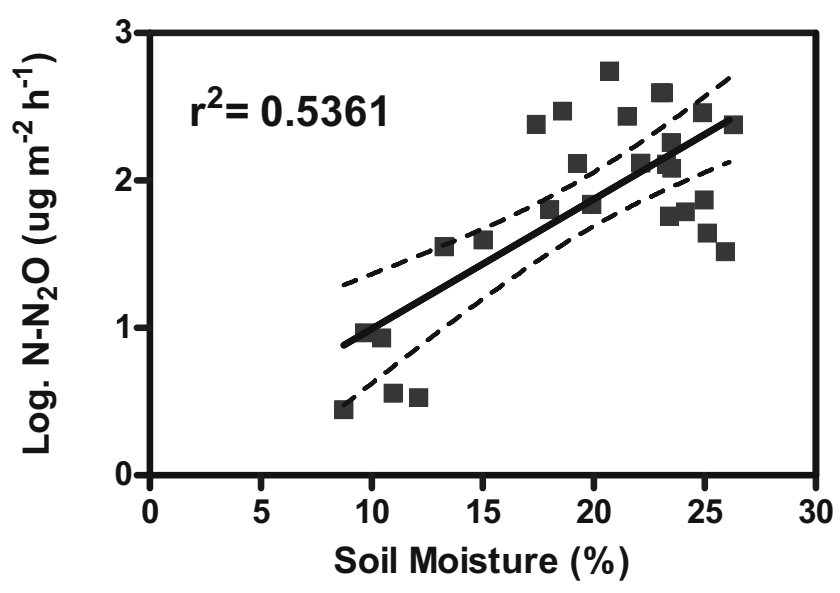

Fig. 4 Relationship between the log-transformed $\mathrm{N}-\mathrm{N}_{2} \mathrm{O}$ emissions with the soil moisture during the grain-filling period to commercial maturity of the soybean crop. Dotted lines represent $95 \%$ confidence intervals

soils (Dobbie and Smith 2003). Bremner (1997) stated that low $\mathrm{NO}_{3}^{-}$concentrations could slow down $\mathrm{N}_{2} \mathrm{O}$ reduction to dinitrogen $\left(\mathrm{N}_{2}\right)$, whereas high concentrations would almost completely inhibit this process (Stevens and Laughlin 1998). As $\mathrm{NO}_{3}^{-}$is lost by denitrification, $\mathrm{N}_{2}$, rather than $\mathrm{N}_{2} \mathrm{O}$, becomes the main produced gas (Stevens and Laughlin 1998) because $\mathrm{NO}_{3}^{-}$is preferred with respect to $\mathrm{N}_{2} \mathrm{O}$ as an electron acceptor (Schlegel 1992). The correlation between $\mathrm{N}_{2} \mathrm{O}$ emission and $\mathrm{NO}_{3}^{-}$levels is even more significant with inoculated plants $\left(r^{2}=0.68 ; P<0.0001\right.$; Fig. $\left.3 b\right)$ probably because rhizodeposition and roots decomposition during the end of the growing season release $\mathrm{C}$ that stimulated growth of heterotrophic microorganisms, including denitrifying bacteria.

Soil moisture is considered one of the main factors regulating N gaseous emissions (McTaggart et al. 1997; Clayton et al. 1997; Dobbie et al. 1999) because it affects the soil redox status (Rowell 1981). However, in the present work, there was not a significant relationship between $\mathrm{N}_{2} \mathrm{O}$ emissions and soil moisture, considering the whole soybean-growing season. Soil moisture was only significantly $\left(r^{2}=0.53 ; P<0.0001\right)$ correlated with $\mathrm{N}_{2} \mathrm{O}$ emissions (Figs. 4 and 5) between the grain-filling period and crop commercial maturity, when there was an increase in the amount of available $\mathrm{N}$ in the soil, probably because of a decrease in $\mathrm{N}$ uptake by the crop and decomposition of $\mathrm{N}$ rich root and nodular debris (Yang and Cai 2005). The interplay between soil moisture and $\mathrm{NO}_{3}^{-}$can explain the smaller $\mathrm{N}_{2} \mathrm{O}$ emissions occurred from sowing to the beginning of fructification-pods formation (R3), when $\mathrm{N}_{2} \mathrm{O}$ emissions decreased, soil moisture was high (30\%), and $\mathrm{NO}_{3}^{-}$content was low because of crop uptake (Fig. 5).

During the period of the highest $\mathrm{N}_{2} \mathrm{O}$ emissions (R5$\mathrm{CM}$ ), the variables that were best correlated to these emissions were soil moisture and $\mathrm{N}-\mathrm{NO}_{3}^{-}$contents; both
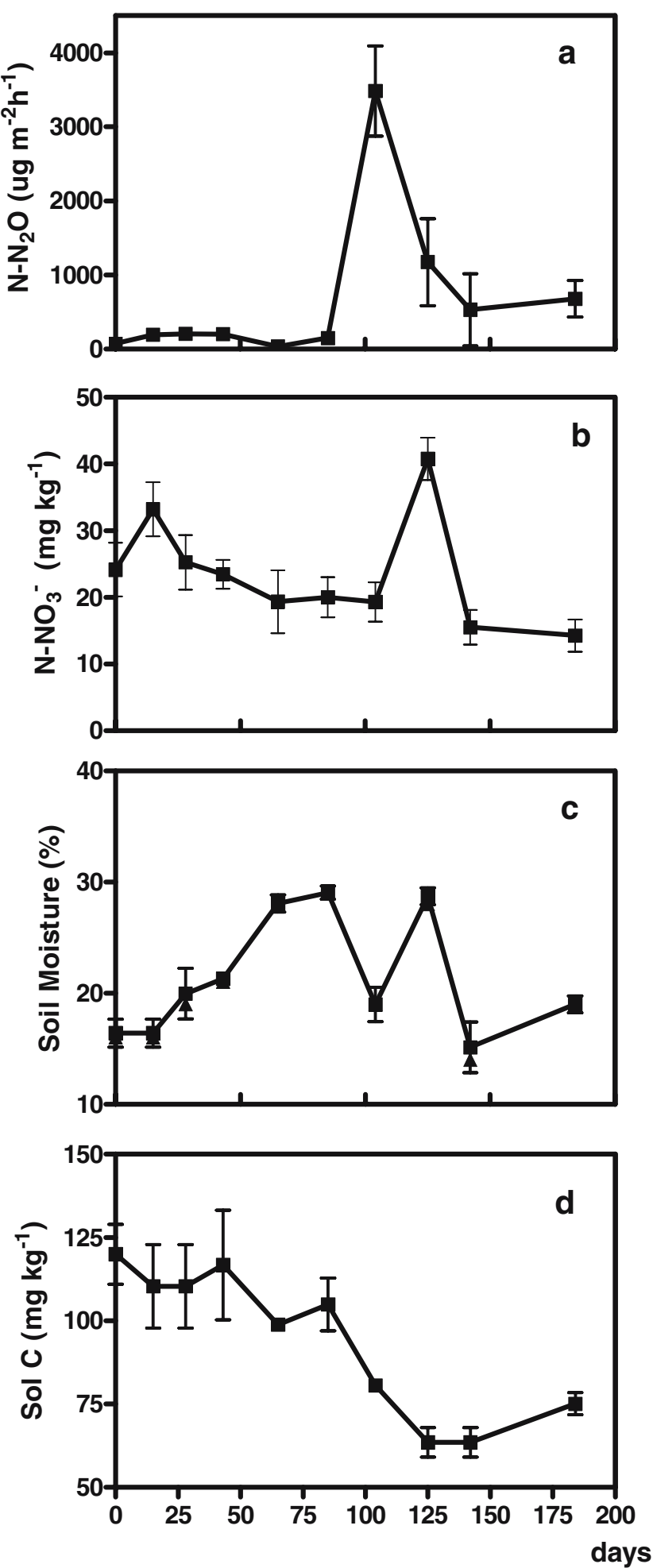

Fig. 5 Evolution of the $\mathrm{N}-\mathrm{N}_{2} \mathrm{O}$ emissions (a) and soil $\mathrm{N}-\mathrm{NO}_{3}^{-}$ contents (b), soil moisture (c), and soluble $\mathrm{C}$ content (d), during the soybean-growing season. Points are average from all treatments. Error bars represented standard deviation (SD)

variables explained the $47 \%$ of the emissions variability; $\mathrm{pH}$ values were not related to $\mathrm{N}_{2} \mathrm{O}$ emissions, probably because these properties showed little changes. Multiple regression analyses were significant $\left(P=0.0018 ; r^{2}=0.47\right)$; 
Fig. 6 Relationship between $\mathrm{N}_{2} \mathrm{O}$ emissions with soluble $\mathrm{C}$ (a) and soil moisture (b) during the stubbles decomposition of the soybean crop. The treatments were separated in: inoculated $(\mathrm{Pi}$, black diamonds) and not inoculated (Pni, gray circles). Dotted lines represent $95 \%$ confidence intervals
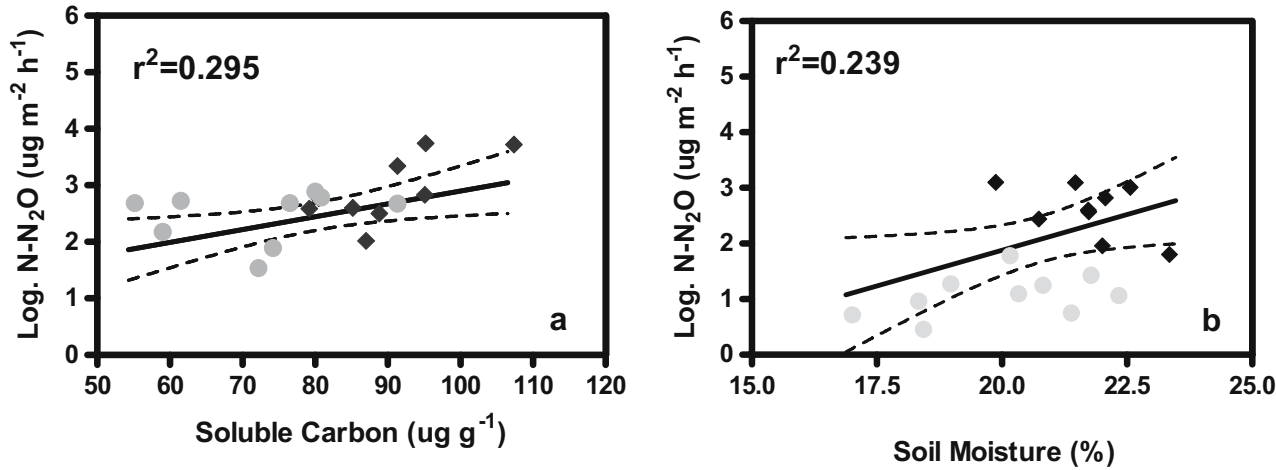

soil moisture $(P=0.0008)$ and $\mathrm{NO}_{3}^{-}(P=0.05)$ positively and significantly correlated with $\mathrm{N}$ emissions. The best relationship explaining the $\mathrm{N}_{2} \mathrm{O}$ emission during soybeangrowing season was

$\mathrm{N}_{2} \mathrm{O}$ emissions $=-2.18+0.09 \times$ soil moisture $(\%)$
$+0.02 \times \mathrm{N}-\mathrm{NO}_{3}^{-}\left(\mathrm{mg} \mathrm{Nkg}^{-1}\right)\left(\mu \mathrm{g} \mathrm{N}-\mathrm{N}_{2} \mathrm{O} \mathrm{m}^{-2} \mathrm{~h}^{-1}\right)$

Period of stubbles decomposition

After commercial maturity, $\mathrm{N}_{2} \mathrm{O}$ emissions decreased (Fig. 1). The postharvest period represented only $30 \%$ of the total experiment duration, and cumulative emissions, $1,068 \mu \mathrm{g} \mathrm{N}-\mathrm{N}_{2} \mathrm{O} \mathrm{m}{ }^{-2} \mathrm{~h}^{-1}$, during this period constituted $28 \%$ of total $\mathrm{N}_{2} \mathrm{O}$ emissions. Despite the important fluxes at the postharvest period, the highest fluxes occurred at the preharvest period (R5-MC) of the soybean crop. This contradicts that observed by Smith et al. (1998), who found that the highest fluxes were observed in the postharvest period of potato crops; these differences with our work may be due to different plant senescence dynamics, $\mathrm{N}$ leaf concentration, and their interactions with soil moisture. It was suggested that labile $\mathrm{C}$ from crop residues promoted sufficient aerobic respiration to induce the formation of anaerobic microsites. Indeed, we found a significant relationship between $\mathrm{N}_{2} \mathrm{O}$ emissions and soluble $\mathrm{C}\left(r^{2}=\right.$ $0.29 ; P=0.019$ ) during stubbles decomposition (Fig. 6a); heterotrophic bacteria, including denitrifiers are controlled by $\mathrm{C}$ availability under aerobic conditions (Palma et al. 1997). In average, higher yields of inoculated plots, $3,207 \mathrm{~kg} \mathrm{ha}^{-1}$, with respect to that of noninoculated plants, $2,627 \mathrm{~kg} \mathrm{ha}^{-1}$, contributed with a great amount of stubbles, with a lower $\mathrm{C} / \mathrm{N}$ ratio (data no shown).

Soil $\mathrm{N}-\mathrm{NO}_{3}^{-}$levels were greater than $15 \mathrm{mg} \mathrm{kg}^{-1}$, but they were not correlated with $\mathrm{N}_{2} \mathrm{O}$ emissions during this time interval, probably because these values were not limiting the $\mathrm{N}_{2} \mathrm{O}$ generating processes. Van Kessell et al. (1993) found that values lower than $10 \mathrm{mg} \mathrm{kg}^{-1} \mathrm{~N}-\mathrm{NO}_{3}^{-}$ concentrations were not limiting denitrification processes, unless favorable conditions for $\mathrm{NO}_{3}^{-}$reduction were present Sainz Rozas et al. (2001) reported that concentrations lower than $40 \mathrm{mg} \mathrm{kg}^{-1} \mathrm{~N}-\mathrm{NO}_{3}^{-}$were limiting for denitrification in typical Argiudoll and petrocalcic Paleudolls soils of the Argentinian Pampean Region. Soil moisture during the period of stubbles decomposition was significantly correlated with $\mathrm{N}_{2} \mathrm{O}$ emissions $\left(r^{2}=0.24 ; P=0.039\right.$; Fig. 6b).

To analyze the effect of stubbles decomposition, data from treatments without plants were excluded in the multiple regression analysis; the relationship was significant $\left(r^{2}=0.50 ; P=0.046\right)$. Soil moisture $(P=0.038)$ and soluble organic $\mathrm{C}(P=0.045)$ content were correlated positively and significantly with $\mathrm{N}_{2} \mathrm{O}$ emissions, whereas soil $\mathrm{NO}_{3}^{-}$content did not influence the magnitude of these losses during the process of stubbles decomposition, confirming the results of the simple linear regressions. The complete model that best explained the emissions during stubbles decomposition period was:

$$
\begin{gathered}
\mathrm{N}_{2} \mathrm{O} \text { emissions }=12.75+0.25 \times \text { moisture }(\%)+0.03 \\
\times \text { soluble } \mathrm{C}\left(\mathrm{mg} \mathrm{kg}^{-1}\right)\left(\mu \mathrm{g} \mathrm{N}-\mathrm{N}_{2} \mathrm{O} \mathrm{m}^{-2} \mathrm{~h}^{-1}\right)
\end{gathered}
$$

\section{Conclusion}

Nitrous oxide emissions increased during the soybean growing season, with the highest accumulation from grain filling until commercial maturity, representing, as an average $1,348 \mu \mathrm{g} \mathrm{N}-\mathrm{N}_{2} \mathrm{O} \mathrm{m}{ }^{-2} \mathrm{~h}^{-1}$, approximately $68 \%$ of total $\mathrm{N}_{2} \mathrm{O}$ emissions. Nitrogen fertilization affected $\mathrm{N}_{2} \mathrm{O}$ losses especially with inoculated soybean plants. Significant correlation was observed between $\mathrm{N}_{2} \mathrm{O}$ emissions and soil $\mathrm{NO}_{3}^{-}$contents with inoculated plants, suggesting that the main controlling variable of $\mathrm{N}_{2} \mathrm{O}$ emissions was $\mathrm{NO}_{3}^{-}$ contents until harvest. Soil moisture and soluble $\mathrm{C}$ but not $\mathrm{NO}_{3}^{-}$content was significantly correlated with the emissions during the stubbles decomposition period. The relationship between controlling factors, soil variables, and $\mathrm{N}_{2} \mathrm{O}$ emissions depended on crop phenological or stubbles decomposition stages. 


\section{References}

Arrese-Igor C, Garcia-Plazaola JI, Hernandez A, Aparicio-Tejo PM (1990) Effect of low nitrate supply to nodulated lucerne on time course of activities of enzymes involved in inorganic nitrogen metabolism. Physiol Plant 80:185-190

Aulakh M, Doran J, Walters D, Mosier A, Francis D (1991a) Crop residue type and placement effects on denitrification and mineralization. Soil Sci Soc Am J 55:1020-1025

Aulakh MS, Doran JW, Mosier AR (1991b) Field evaluation of four methods for measuring denitrification. Soil Sci Soc Am J 55:1332-1338

Bouwman AF (1996) Direct emissions of nitrous oxide from agricultural soils. Nutr Cycl Agroecosyst 46:53-70

Bray RH, Kurtz LT (1945) Determination of total, organic and available forms of phosphorous in soil. Soil Sci 134:376-380

Breitenbeck GA, Bremner JM (1989) Ability of free living Bradyrhizobium japonicum to denitrify nitrate in soils. Biol Fertil Soils 7:219-224

Bremner JM (1997) Sources of nitrous oxide in soils. Nutr Cycl Agroecosyst 49:7-16

Brown HA, Waggner-Riddle C, Thurtell GW (2000) Nitrous oxide flux from solid dairy manure in storage as affected by water content and redox potential. J Environ Qual 29:630-638

Carole RS, Scarigelli FP (1971) Colorimetric determination of nitrate after hydrazine reduction to nitrite. Microchem J 16:657-672

Castaldi S (2000) Responses of nitrous oxide, dinitrogen and carbon dioxide production and oxygen consumption to temperature in forest and agricultural light-textured soils determined by model experiment. Biol Fertil Soils 32:67-72

Ciampitti IA, Ciarlo EA, Conti ME (2005) Nitrous oxide emission during soybean culture: inoculation and nitrogen fertilization effects. Ci Suelo 23:123-131

Clayton H, McTaggart IP, Parker J, Swan L, Smith KA (1997) Nitrous oxide emissions from fertilised grassland: a 2-year study of the effects of $\mathrm{N}$ fertiliser form and environmental conditions. Biol Fertil Soils 25:252-260

Daum D, Schenk MK (1998) Influence of nutrient solution $\mathrm{pH}$ on $\mathrm{N}_{2} \mathrm{O}$ and $\mathrm{N}_{2}$ emissions from a soilless culture system. Plant Soil 203:279-287

Dobbie KE, Smith KA (2003) Impact of different forms of $\mathrm{N}$ fertilizer on $\mathrm{N}_{2} \mathrm{O}$ emissions from intensive grassland. Nutr Cycl Agroecosyst 67:37-46

Dobbie KE, McTaggart IP, Smith KA (1999) Nitrous oxide emissions from intensive agricultural systems: variations between crops and seasons, key driving variables, and mean emission factors. J Geophys Res 104:26891-26899

Duxbury JM, Bouldin DR, Terry RE, Tate RL III (1982) Emissions of nitrous oxide from soils. Nature 298:462-464

Ghosh S, Majumdar D, Jain MC (2002) Nitrous oxide emissions from kharif and rabi legumes grow on an alluvial soil. Biol Fertil Soils 35:473-478

Goodroad LL, Keeney DR (1984) Nitrous production in aerobic soils under varying $\mathrm{pH}$, temperate and water content. Soil Biol Biochem 16:39-43

Heckman MO, Drevon JJ (1987) Nitrate metabolism in soybean root nodules. Physiol Plant 69:721-725

Henault C, Devis X, Page S, Justes E, Reau R (1998) Nitrous oxide emissions under different soil and land management conditions. Biol Fertil Soils 26:199-207

Houghton JT, Ding Y, Griggs DJ, Noguer M, Van der Linden PJ, Dai X, Maskell K, Johnson CA IPCC (2001) Climate change 2001: the scientific basis. Cambridge University Press, Cambridge, UK

Hunter WJ (1983) Soybean root and nodule nitrate reductase. Physiol Plant 59:471-475

INDEC (2005). http://www.indec.gov.ar
Kaiser EA, Kohrs K, Kucke M, Schnug E, Heinemeyer O, Munch JC (1998) Nitrous oxide release from arable soil: importance of $\mathrm{N}$ fertilization, crops and temporal variation. Soil Biol Biochem 30:1553-1563

Khera TS, Aulakh MS, Doran JW (1999) Significance of soil depth on nitrogen transformations in flooded and nonflooded systems under laboratory conditions. Nutr Cycl Agroecosyst 54:209-213

Luciñski R, Polcyn W, Ratajczak L (2002) Nitrate reduction and nitrogen fixation in symbiotic association Rhizobium-legumes. Acta Biochim Pol 49:537-546

MacKenzie AF, Fan MX, Cadrin F (1998) Nitrous oxide emission in three years as affected by tillage, corn-soybean-alfalafa rotations, and nitrogen fertilization. J Environ Qual 27:698-703

Maggiotto SR, Webb JA, Waggner-Riddle C, Thurtell GW (2000) Nitrous and nitrogen oxide emissions from turfgrass receiving different forms of nitrogen fertilizer. J Environ Qual 29: 621-630

Marinho EV, DeLaune RD, Lindau CW (2004) Nitrous Oxide flux from soybeans grown on Mississippi Alluvial Soil. Commun Soil Sci Plant Anal 35:1-8

Mazzarino MJ, Szott L, Jimenez M (1993) Dynamics of soil total C and $\mathrm{N}$, microbial biomass, and water-soluble $\mathrm{C}$ in tropical agroecosystems. Soil Biol Biochem 25:205-214

McTaggart IP, Clayton H, Parker J, Swan L, Smith KA (1997) Nitrous oxide emissions from grassland and spring barley, following $\mathrm{N}$ fertiliser application with and without nitrification inhibitors. Biol Fertil Soils 25:261-268

Mogge B, Kaiser EA, Munch JC (1999) Nitrous oxide emissions and denitrification $\mathrm{N}$-losses from agricultural soils in the Bornhoved lake region: influence of organic fertilizers and land-use. Soil Biol Biochem 31:1245-1252

Mosier AR (1998) Soil processes and global change. Biol Fertil Soils 27:221-229

Mosier AR, Duxbury JM, Freney JR, Heinemeyer O, Minami K (1996) Nitrous oxide emissions from agricultural fields: assessment, measurement and mitigation. Plant Soil 181:95-108

Nelson DW, Sommers LE (1982) Total carbon, organic carbon and organic matter. In: Page AL (ed) Methods of soil analysis. Part 2. American Society, of Agronomy, USA, Agronomy 9, Madison, WI, pp 539-579

Palma RM, Rímolo M, Saubidet MI, Conti ME (1997) Influence of tillage system on denitrification in maize-cropped soils. Biol Fertil Soils 25:142-146

Rochette P, Angers D, Belanger G, Chantigny M, Prevost D, Levesque G (2004) Emissions of nitrous oxide from alfalfa and soybean crops in eastern Canada. Soil Sci Soc Am J 68: 493-506

Rowell DL (1981) Oxidation and reduction. In: Greenland DJ, Hayes MHB (eds) The chemistry of soil processes. Wiley, Avon, pp 401-462 (ISBN 0471279636)

Sainz Rozas HR, Echeverría HE, Picone LI (2001) Denitrfication in Maize under no-tillage: Effect of nitrogen rate and application time. Soil Sci Soc Am J 65:1314-1323

SAS Institute (1999) SAS/STAT guide for personal computers, version 8. SAS Institute, Cary, NC

Schlegel HG (1992) Allgemeine mikrobiologie, 7th edn. Thieme, Stuttgart, New York

Sexstone AJ, Parkin TB, Tiedje JM (1985) Temporal response of denitrification rates to rainfall and irrigation. Soil Sci Soc Am J 49:99-103

Smith KA, McTaggart IP, Dobbie KE, Conen F (1998) Emissions of $\mathrm{N}_{2} \mathrm{O}$ from Scottish agricultural soils, as a function of fertilizer $\mathrm{N}$. Nutr Cycl Agroecosyst 52:123-130

Stevens RJ, Laughlin RJ (1998) Measurement of nitrous oxide and dinitrogen emissions from agricultural soils. Nutr Cycl Agroecosyst 52:131-139 
Thomas GW (1996) Soil pH and soil acidity. In: Sparks DL (ed) Methods of soil analysis. Part 3. Soil Science Society of America, Madison, WI, pp 475-490

Van Kessell C, Pennock DJ, Farrell RE (1993) Seasonal variations in denitrification and nitrous oxide evolution at the landscape scale. Soil Sci Soc Am J 57:988-995

Watson RT (1992) Climate change 1992. The supplementary reports to the IPCC scientific assessment. In: Houghton JT, Callander BA, Varney SK (eds) Greenhouse gases: sources and sinks. Cambridge University Press, New York, NY, pp 25-46

Weitz AM, Linder E, Frolking S, Crill PM, Keller M (2001) $\mathrm{N}_{2} \mathrm{O}$ emissions from humid tropical agricultural soils: effects of soil moisture, texture and nitrogen availability. Soil Biol Biochem 33:1077-1093

Williams DL, Ineson P, Coward PA (1999) Temporal variations in nitrous oxide fluxes from urine-affected grassland. Soil Biol Biochem 31:779-788

Yang L, Cai Z (2005) The effect of growing soybean (Glycine $\max$ L.) on $\mathrm{N}_{2} \mathrm{O}$ emission from soil. Soil Biol Biochem 37: 1205-1209

Zheng X, Wang M, Wang Y, Shen R, Gou J, Li J, Jin J, Li L (2000) Impacts of soil moisture on nitrous oxide emissions from croplands: a case study on the rice-based agro-ecosystem in Southeast China. Chemosphere Glob Chang Sci 2:207-224 